\title{
Lichen biota of the "Wrzosowiska Cedyńskie im. inż. Wiesława Czyżewskiego" nature reserve in the Cedynia Landscape Park (NW Poland)
}

\author{
ANETTA WIECZOREK, ${ }^{1}$ ANDRZEJ ŁYSKO ${ }^{2}$ \\ Department of Ecology, Institute for Research on Biodiversity, Faculty of Biology, University of Szczecin, Wąska 13, 71-412 Szczecin, \\ Poland, "corresponding author: anettaw@univ.szczecin.pl \\ 2 Department of Environmental Protection and Management, Western Pomeranian University of Technology, Szczecin, Poland, e-mail: \\ andrzejlysko@gmail.com
}

Keywords $\quad$ xerothermic lichens, rare lichens, protected species, threatened lichens, nature reserve, NW Poland

Abstract Lichens of the "Wrzosowiska Cedyńskie im. inż. Wiesława Czyżewskiego" nature reserve were studied in 2005 and 2011. Within the examined area, 103 species of lichens were observed. These include 23 species that are new to this area, some of them calciphilous, e.g. Agonima gelatinosa and Collema crispum. Many of them are rare in the Polish lowlands, e.g. Cladonia stellaris, Rhizocarpon geographicum, R. polycarpum, Stereocaulon condensatum, and $S$. incrustatum.

Biota porostów rezerwatu "Wrzosowiska Cedyńskie im. inż. Wiesława Czyżewskiego" w Cedyńskim Parku Krajobrazowym

Słowa kluczowe porosty kserotermiczne, porosty rzadkie, gatunki chronione, porosty zagrożone, rezerwat przyrody, NW Polska

Streszczenie Porosty rezerwatu "Wrzosowiska Cedyńskie im. Wiesława Czyżewskiego" badano w 2005 i 2011 roku. Na badanym obszarze zaobserwowano 103 gatunki porostów. Wśrod nich 23 taksony to gatunki nowe na tym obszarze, niektóre z nich to porosty kalcyfilne np. Agonima gelatinosa i Collema crispum. Wiele z nich jest rzadkich na polskich nizinach, np. Cladonia stellaris, Rhizocarpon geographicum, R. polytropa, Stereocaulon condensatum i S. incrustatum.

\section{Introduction}

Xerothermic grasslands in Pomerania are the northern most relict steppe communities in Poland. They develop in the places where edaphic and microclimatic conditions are similar to those characteristic of the plant formations of steppes and forest steppes. They are found 
primarily on S- and W-facing slopes of valleys of the lower Oder (Odra), Vistula, and in the Torun-Eberswalde Proglacial Valley (Pradolina Toruńsko-Eberswaldzka).

Soils overgrown by xerothermic vegetation are fertile and rich in calcium carbonate. Such conditions are favourable for development of lichens of two groups: xerothermophytes and calciphiles, i.e. species found on limestones or on other substrates containing calcium (Czyżewska, 1986). Xerothermic species of lichens are floristic curiosities in the western part of Polish Pomerania, as they are usually found in mountains and uplands. Some xerothermic lichens have been reported from the lowlands of Poland (e.g. Tobolewski, 1962; Glanc, 1964; Ceynowa-Giełdon, 1993, 2001; Ceynowa-Giełdon, Glazik, 1994; Ceynowa-Giełdon et al., 2004; Czyżewska, 1986; Wójciak, 1987), but the most characteristic species of xerothermic grasslands are threatened in the central part of the European Lowland (Aptroot et al., 2011; Dolnik et al., 2010; Hauck, de Bryun, 2010; Litterski, Schiefelbein, 2007; Otte, Ratzel, 2004; Søchting, Alstrup, 2008). This is due to the usually small size of patches of such habitats and their geographic division, but also to less frequent use of the land, especially stopping sheep grazing.

Here, the importance of habitats of this type for the biota of lichens of north-western Poland is discussed on the basis of the current species composition of lichens in this reserve, with particular reference to the earlier disregarded xerothermic lichens.

\section{Study area}

The "Wrzosowiska Cedyńskie im. inż. Wiesława Czyżewskiego" nature reserve, covering an area of 72.02 ha, is situated in the western part of the Cedynia Landscape Park, about $3 \mathrm{~km}$ southwest of the town of Cedynia. It is composed of patches of heaths of the alliance Pohlio-Callunion (Matuszkiewicz, 2001) and xerothermic grasslands of the class Festuco-Brometea, which are rare in Central and Western Europe. The reserve was created in 1985, based on documents prepared by Ćwikliński (1976). Its northern boundaries run along the Cedynia-Osina road, eastern along the valley bottom at the forest fringe, southern along the plateau, and western along the valley bottom.

The reserve lies on moraine hills made of postglacial, slightly loamy sands, reaching up to $50 \mathrm{~m}$ above sea level. The protected area covers the hillocks distinguished by their varied shape and vegetation. It is an almost woodless area, dominated by common heather Calluna vulgaris (Figure 1) and xerothermic plants. Herbaceous plants within the heather patches include German greenweed Genista germanica, carline thistle Carlina vulgaris, mouse-ear hawkweed Hieracium pilosella, and field wood-rush Luzula campestris (Ćwikliński, 1976; Ziarnek et al., 2006). Among the grasses, there are many stones and boulders, which are microhabitats for epilithic lichens.

In total, 89 species of lichens were reported from the reserve in 1976-2013, including 41 epigeic, 26 epiphytic, and 20 epilithic species. (Ćwikliński, 1976; Ziarnek et al., 2006; Ciaciura et al., 2008; Wieczorek, Schiefelbein, 2013). Considering the specific microclimatic conditions, special attention should be paid to xerothermic lichens found in the reserve. High temperatures of the top layer of the soil and high concentrations of calcium carbonate create favourable conditions for development of xerothermic lichens, which are rare in Pomerania. In the study area they were represented by e.g. Bacidia bagliettoana, Blenothallia crispa, Cladonia foliacea, C. pocillum, Enchylium tenax, and Placidium squamulosum. 


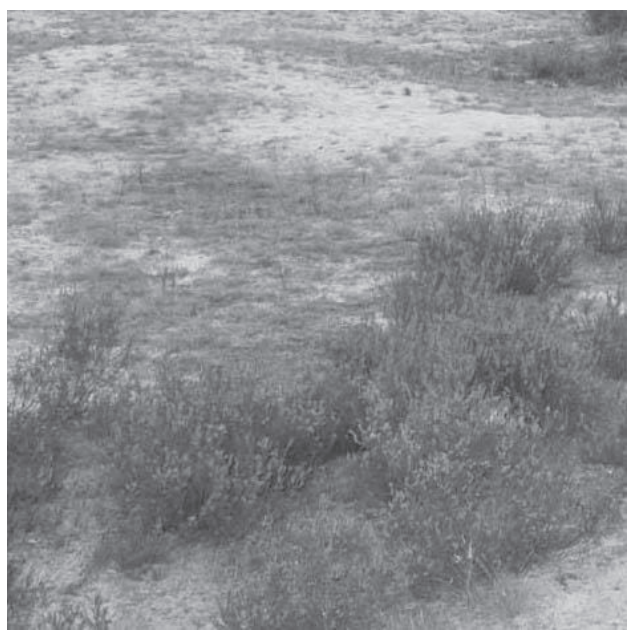

Figure 1. Sandy grassland with Calluna vulgaris

\section{Material and methods}

The study was conducted in 2007-2010. A map used in the fieldwork was divided into a grid of $100 \mathrm{~m} \times 100 \mathrm{~m}$ squares, numbered as in Figure 2. Each square $\left(100 \mathrm{~m} \times 100 \mathrm{~m}=10000 \mathrm{~m}^{2}\right)$ was regarded as one locality. In total, 365 lichen specimens were collected and deposited in the Lichen Herbarium of the Department of Ecology and Environmental Protection of the University of Szczecin. The species are listed alphabetically, with information on their localities (square numbers) and type of substratum. Terminology was adopted from Fałynowicz and Kossowska (2016). Threat categories (EN, VU, NT) are given according to the "Red List of extinct and threatened lichens in Poland" (Cieśliński et al., 2006).

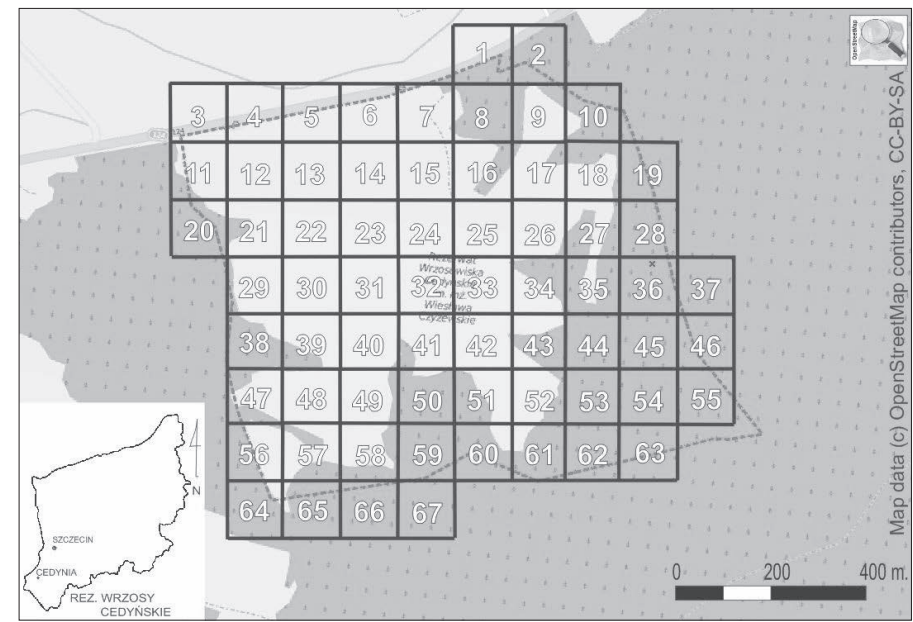

Figure 2. Distribution of grid squares 


\section{Results}

In the study area, 103 lichen species were recorded as a result of field research. The most frequently represented ecological group were epigeic lichens, which account for $42 \%$ of the total number of species. This is understandable because of the small number of woody plants in the reserve. About $26 \%$ of the total number of species are epiphytic lichens, growing on the bark of various trees growing on the fringe of the study area. The least numerous ecological groups are epilithic lichens occurring on rocks (19\%) and epixylic lichens found on dead wood of tree trunks and branches $(10 \%)$, because of a lack of substrata suitable for the development of that ecological group (Figure 3).

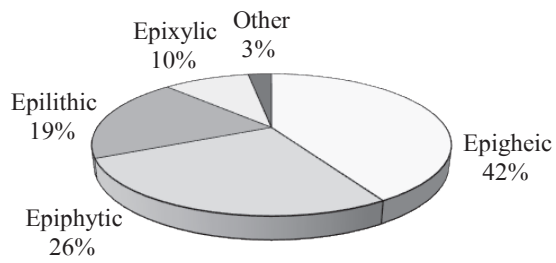

Figure 3. Percentage of species from various ecological groups

Epigeic lichens constitute an important component of the plant cover of the reserve, as 47 epigeic lichen species were recorded within the study area. A vast majority of them (41 taxa) are typical of dry and acidic sandy grasslands (Figure 4). Species with fruticose thalli prevail among epigeic lichens (Figure 5) and are represented first of all by common taxa of the genus Cladonia. Out of the 29 recorded species of that genus, most are typical of sandy grasslands. The most frequently recorded psammophilous species are C. fimbriata, C. furcata, C. macilenta, C. foliacea, C. subulata, C. chlorophaea s.1., and C. uncialis. Among crustose epigeic lichens, constituting barely $15 \%$ of the soil-growing species (Figure 3 ), the most frequently recorded ones include Placynthiella oligotropha, P. uliginosa, and Trapeliopsis granulosa.

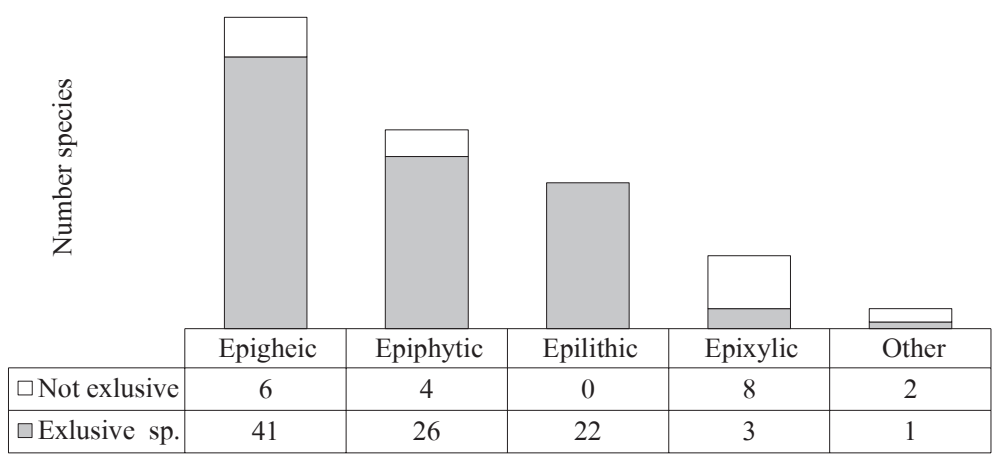

Figure 4. Shares of ecological groups in exclusive and non-exclusive species lichen biota 


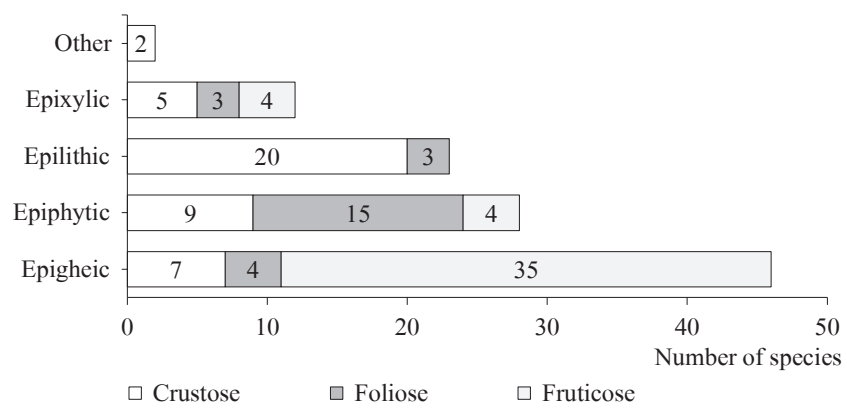

Figure 5. Spatial distribution of lichen species and contribution morphological forms in each

Out of the 103 recorded lichen species, 30 were epiphytic, found on the bark of various tree species. They were usually common taxa, widespread in Poland, e.g. Hypocenomyce scalaris, Hypogymnia physodes, Lecanora conizaeoides, Physcia tenella, Parmelia sulcata, Parmeliopsis ambigua, Scoliciosporum chlorococcum, Xanthoria parietina, and X. polycarpa. However, species like Evernia prunastri, Hypogymnia tubulosa, Lecidella elaeochroma, Melanelixia fuliginosa, Physcia adscendens, Physconia grisea, and Platismatia glauca, were only sporadically recorded in Pomerania. Out of all the morphological forms of that group of lichen species, decidedly most abundant ones are those with foliose thalli, constituting 53\% of the epiphytic lichens (Figure 5). Special attention should be paid to Usnea hirta and Pleurosticta acetabulum, found in single locations, as they are red-listed in Poland. Although they occur in single locations in the reserve, they are quite frequent in other parts of the West Pomerania Province.

\section{Discussion}

Out of the 103 species recorded in this study, 24 were not reported earlier (Ćwikliński, 1976; Ziarnek et al., 2006; Ciaciura et al., 2008; Wieczorek, Schiefelbein, 2013).

Populations of lichens typical of sandy grasslands are very numerous within the area under study and form extensive carpets interspersed with heather shrubs and tufts of moss and flowering plants. The bare sandy soil is overgrown with C. arbuscula, C. ciliata, C. coccifera, C. glauca, C. phyllophora, C. pleurota, C. polydactyla, C. portentosa, C. pyxidata, and C. cervicornis subsp. verticillata. Among the epigeic lichen species, only a few are forest acidophytes, occurring not only on sandy grasslands but also quite frequent in dry pine forests and thickets on sandy soils, e.g. C. cornuta, C. deformis, C. digitata, C. rangiferina, and C. squamosa. Between those lichens, small thalli of Cetraria aculeata, C. islandica, and Peltigera didactyla can be found sporadically. Within the group of epigeic lichen species, special attention should be paid to the lichens that are very rare in Western Pomerania (Fałtynowicz, 1992). They include Cladonia stellaris, Cetraria muricata, Stereocaulon condensatum, and S. incrustatum, which in the study area form very small populations. Despite repeated searches, their single thalli were observed in single locations only.

The most interesting lichens are calciphilous species, as xerothermic grasslands are rare in Pomerania. Species of this group are most abundant in Poland in mountains and uplands within the belt of limestones. In other areas of our country, xerothermic grasslands are observed on steep slopes of river valleys, particularly of the Oder and Vistula, or on the moraine hills 
exposed to the south. In the "Wrzosowiska Cedyńskie im. inż. Wiesława Czyżewskiego" nature reserve, 10 xerothermic lichen species were recorded. The most frequent among them is Bacidia bagliettoana. It is found between tall grasses, on bare soil. In Poland it is one of the most widespread xerothermic lichens (Fałtynowicz, 1992; Ceynowa-Giełdon, 2001; Wieczorek, Schiefelbein, 2013). Apart from this species, small foliose thalli of Enchylium tenax, Placidium squamulosum and slightly larger ones of Peltigera rufescens occur with a similar frequency. Out of the xerothermic lichens with fruticose thalli, the most frequent is Cladonia pyxidata. Apart from it, the photophilous and calciphilous species Agonimia gelatinosa, Blenothallia crispa, and Diploschistes muscorum are observed sporadically. A species very rarely occurring on uncovered limestone hillsides in the higher parts of slopes and tops is Rufoplaca arenaria, with characteristic orange ascocarps (apothecia), known in Western Pomerania from several locations (Fałtynowicz, 1992). Xerothermic species include also Cladonia foliacea and C. rangiformis according to some authors (Fałtynowicz, 1992).

The group of epiphytic lichens, despite a relatively small area being occupied by trees and shrubs in the reserve, is very rich. On the one hand, it is connected with the presence of extensive forest areas around the reserve, but on the other hand, with the forest-heath ecotone on the border with extensive woodless areas of the reserve. As a result, photophilous and dust-loving (pollutiontolerant) lichen species, e.g. Xanthoria polycarpa or X. parietina, are observed here, apart from the typical forest lichens, like Bryoria spp.

The occurrence of rare lichen taxa of natural bedrocks in Pomerania also deserves attention. A substratum for epiphytic lichens in the reserve are stones of various size and shape, scattered between heather and grass patches, but also small concrete border posts. The richest lichen patches are observed on stones in the open ground. Among the various morphological forms, crustose lichens prevail, constituting $83 \%$ of all epilithic species. Characteristic species growing on stones are Acarospora fuscata, Lecanora polytropa, Protoparmeliopsis muralis, Lecidea grisella, and Rusavskia elegans, while Lecania erysibe, Rhizocarpon polycarpum, and $R$. geographicum were very rare, on single stones. The latter group of taxa are very rare in the lowlands, but more frequent in higher, mountainous locations. In shady places, between tall grasses, substantially fewer lichen species were observed on stones, those including Porpidia crustulata, Trapelia placodioides, and Verrucaria nigrescens. On concrete posts, calciphilous lichens typical for that habitat were observed, e.g. Myriolecis dispersa or Candelariella aurella.

Within the "Wrzosowiska Cedyńskie im. inż. Wiesława Czyżewskiego" nature reserve, the occurrence of 13 red-listed species (Cieśliński et al., 2006) was observed, and they constitute $13 \%$ of the total number of lichens recorded in this study (Figure 6). Particularly valuable are endangered species (EN), such as Cladonia stellaris (occurring in a small fragment of pine forest), Pleurosticta acetabulum (observed on the bark of a lonely birch by the road), and Stereocaulon incrustatum (found between other lichen taxa on bare soil). Other red-listed lichen species in the reserve are: Bryoria fuscescens, Cetraria islandica, Stereocaulon condensatum, Tucermanopsis chlorophylla, and Usnea hirta, representing the category of vulnerable taxa (VU), and Cetraria muricata, Evernia prunastri, Hypogymnia tubulosa, Placidium squamulosum, and Vulpicidia pinastris, representing the category of near-threatened taxa (NT). All of these lichens were observed in single locations. No signs of degeneration, such as discolouration or missing reproduction organs, were observed on the thalli of these species but it is difficult to predict transformations and the direction of changes in the lichen due to the lack of earlier detailed lichenological data from this area. 


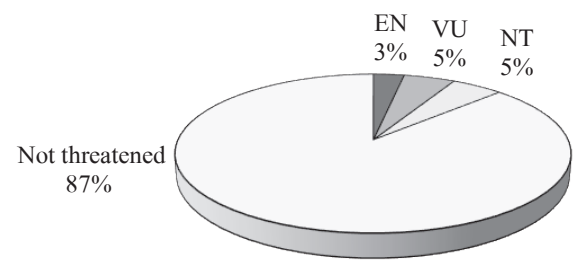

Figure 6. Numbers of lichen species in particular threat categories (Cieśliński et al., 2006): EN = endangered; $\mathrm{VU}=$ vulnerable; $\mathrm{NT}=$ near threatened

Within the area of the reserve, the occurrence of 23 species protected by Polish law was recorded (marked with PR in the species list below).

Despite the impact of many anthropogenic factors, including trampling in particular, the diversity of lichens in the reserve is very high, with many interesting and rare species. They represent the taxa mostly specialised and adapted to specific habitat conditions, so good prospects for their preservation are created by the local ecological conditions.

\section{List of species}

For each species, the type of substrate on which it is found and square numbers are given.

Symbols: ! = new species for the "Wrzosowiska Cedyńskie im. inż. Wiesława Czyżewskiego" nature reserve: $\mathrm{CR}=$ critically endangered, $\mathrm{EN}=$ endangered, $\mathrm{VU}=$ vulnerable, $\mathrm{NT}=$ near threatened; $\mathrm{PR}=$ strict or partial protection.

Acarospora fuscata (Nyl.) Arnold - on stones: 35, 41.

!Agonimia gelatinosa (Ach.) Brand \& Diederich - on soil: 26.

Amandinea punctata (Hoffm.) Coppins \& Scheid. - on birch tree bark: 1, 39, 50.

Aspicilia cinerea (L.) Körb. - on stone: 41.

Athalia holocarpa (Hoffm.) Arup, Frödén \& Søchting - on a concrete post: 7.

Bacidia bagliettoana (A. Massal. \& De Not.) Jatta - on soil: 8, 12, 21, 35, 40, 43.

!Blenothallia crispa (Huds.) Otálora, P.M. Jørg. \& Wedin - on soil: 33, 35.

Bryoria fuscescens (Gyeln.) Brodo \& D. Hawksw. - [PR, VU], on birch tree bark: 29.

Calogaya decipiens (Hoffm.) Arup, Frödén \& Søchting - on a concrete post: 7.

!C. pusilla (A. Massal.) Arup, Frödén \& Søchting - on a concrete post: 7.

Candelaria concolor (Dicks.) Stein - on birch, and oak tree bark: 45, 50.

Candelariella aurella (Hoffm.) Zahlbr. - on stones: 13, 26.

C. coralliza (Nyl.) H. Magn. - on stones: 7, 13.

C. vitellina (Hoffm.) Müll. Arg. - on stones and on a concrete post: 16, 35, 38.

!C. xanthostigma (Ach.) Lettau - on birch tree bark: 5 .

Cetraria aculeata (Schreb.) Ach. - on soil: 4, 6-8, 12, 14, 16, 17, 21, 24-26, 29-33, 39, 40, 43.

C. islandica (L.) Ach. - [PR, VU], on soil: 21, 39.

C. muricata (Ach.) Eckfeldt - [PR, NT], on soil: 12, 30.

Cladonia arbuscula (Wallr.) Flot. em. Ruoss subsp. mitis (Sandst.) Ruoss - on soil: 12, 32, 33.

C. arbuscula (Wallr.) Flot. subsp. squarrosa (Wallr.) Ruoss - on soil: 12, 21, 29-31, 40. 
C. cenotea (Ach.) Schaer. - on soil: 40.

C. cervicornis (Ach.) Flot. subsp. verticillata (Hoffm.) Ahti - on soil: 12-15, 21, 27, 29, 36.

C. chlorophaea s.1. (Flörke ex Sommerf.) Spreng. - on soil, and wood: 4-9, 12-18, 21-27, 29-36, 40-43.

C. ciliata Stirt. Harm. var. tenuis (Flörke) Nimis - [PR], on soil: 4, 12, 21, 32, 33.

C. coccifera (L.) Willd. - on soil: 32, 41, 57.

C. coniocraea auct. - on soil, and at the base of a pine tree trunk: 1, 5, 8, 11, 26, 28, 29, 39, 44, $45,48,50-66$.

C. cornuta (L.) Hoffm. - on soil: 16, 17, 39, 40.

C. deformis (L.) Hoffm. - on soil: 6, 25, 30, 36.

C. digitata (L.) Hoffm. - on soil: 4, 5, 8, 13, 15, 16, 30, 33, 34, 49.

C. fimbriata (L.) Fr. - on soil, and wood: 4-19, 21-23, 25, 28, 29, 31, 32, 35-45, 48-51, 53-60, $62,63$.

C. floerkeana (Fr.) Flörke - on soil: 5, 6, 9, 11-13, 21, 23, 27, 30, 36, 39, 49.

C. foliacea (Huds.) Willd. - on soil: 4-9, 11-17, 21-26, 29-35, 40, 42.

C. furcata (Huds.) Schrad. - on soil: 4-9, 12-18, 21, 22, 24-27, 29-36, 39-43,48, 49, 57.

C. glauca s. 1. Flörke - on soil: 5, 12, 35, 43.

C. gracilis (L.) Willd. - on soil: 4, 12.

C. macilenta Hoffm. - on soil, and wood: 4, 6, 7, 9, 10, 12-18, 21-24, 26-29, 32-34, 39-43, 47-49, 51, 57.

C. phyllophora Hoffm. - on soil: 22, 26, 31, 35, 40.

C. pleurota (Flörke) Schaer. - on soil: 11, 33, 36.

C. polydactyla (Flörke) Spreng. - on soil: 5, 7, 8, 12, 13.

C. portentosa (Dufour) Coem. - [PR], on soil: 7-9, 16, 34.

C. pocillum (Ach.) O.-J. Rich. - on soil: 17, 18, 21, 30, 40.

C. pyxidata (L.) Hoffm. - on soil: 7, 8, 12, 13, 17, 23, 26, 30, 36, 48, 49.

C. rangiferina (L.) Weber - on soil: 5, 8, 9, 12, 14, 21, 29, 39.

C. rangiformis Hoffm. - on soil: 4, 7 .

C. scabriuscula (Delise) Nyl. - on soil: 4, 9, 12.

C. squamosa (Scop.) Hoffm. - on soil: 22, 23.

C. stellaris (Opiz) Pouzar \& Vězda - [PR, EN], on soil: 21.

C. subulata (L.) Weber - on soil, and wood: 4-9, 11-17, 21-26, 29-35, 40, 42.

C. uncialis (L.) F.H. Wigg. - on soil: 5-9, 11-17, 2123, 25, 26, 29-35, 40, 42.

Coenogonium pineti (Schrad.) Lücking \& Lumbsch - on oak tree bark: 50, 54.

!Diploschistes muscorum (Scop.) R. Sant. - on soil: 32, 34.

Enchylium tenax (Sw.) Gray - on soil: 32-34, 41, 42.

Evernia prunastri (L.) Ach. - [NT], on birch tree bark: 1.

!Fellhanera subtilis (Vězda) Diederich \& Sérus. - on small branches of Calluna vulgaris: 15.

Hypocenomyce scalaris (Ach.) M. Choisy - on pine, and birch tree bark, and wood: 1, 2, 11, 18, $23,38,45,48,50-55,57-63,65$.

Hypogymnia physodes (L.) Nyl. - on pine, and birch tree bark: 1-5, 7, 9-11, 18, 19, 29, 38, 39, 43-48, 50-67.

H. tubulosa (Schaer.) Hav. - [PR, NT], on birch tree bark: 5, 8, 9, 43.

!Lecania erysibe (Ach.) Mudd - on stones: 16, 21.

Lecanora conizaeoides Nyl. - on pine, and birch tree bark: 1, 2, 8, 9, 29, 38, 47, 50, 51, 53, 55.

L. polytropa (Ehrh. ex Hoffm.) Rabenh. - on stones: 28, 30. 
L. pulicaris (Pers.) Ach. - on birch, and poplar tree bark: 43, 44, 59.

Lecidea fuscoatra (L.) Ach. - on stones: 22, 24, 25.

!Lecidella elaeochroma (Ach.) Choisy - on birch tree bark: 3, 8 .

Lepraria incana (L.) Ach. - on tree bark, and wood: 1, 2, 8-11, 29, 38, 43-47, 50-66.

!Melanelixia fuliginosa (Fr. ex Duby) O. Blanco \& al. - on birch tree bark: 2.

!Micarea denigrata (Fr.) Hedl. - on wood: 18.

Myriolecis dispersa (Pers.) Śliwa, Zhao Xin \& Lumbsch - on concrete posts: 8 .

Parmelia sulcata Taylor - on pine, and birch tree bark: 1-3, 7, 28, 57, 58, 62, 63.

Parmeliopsis ambigua (Wulfen) Nyl. - on pine, and birch tree bark, and wood: 1-3, 7, 9, 10, 11, 44.

Peltigera didactyla (With.) J.R. Laundon - [PR], on soil: 7, 12, 29.

P. rufescens (Weiss) Humb. - on soil: 11.

!Phaeophyscia nigricans (Flörke) Moberg - on concrete posts: 57.

!P. orbicularis (Neck.) Moberg - on concrete posts: 57.

Phlyctis argena (Ach.) Flot. - on oak tree bark: 6, 10.

Physcia adscendens Fr. H. Olivier - on birch tree bark: 2.

P. tenella (Scop.) DC. - on birch tree bark: 2, 7.

!Physconia grisea (Lam.) Poelt - on birch tree bark: 7.

Placidium squamulosum (Ach.) O. Breuss - [NT], on soil: 16, 21, 24, 25.

!Placynthiella icmalea (Ach.) Coppins \& P. James - on soil: 5, 6, 9.

!P. oligotropha (Vain.) Coppins \& P. James - on soil: 5, 8, 9, 11, 12, 15, 17, 30, 34.

!P. uliginosa (Schrad.) Coppins \& P. James - on soil, and wood: 3, 6-8, 22, 27, 39, 40.

Platismatia glauca (L.) W.L. Culb. \& C.F. Culb. - on birch tree bark: 1, 3, 50.

!Pleurosticta acetabulum (Neck.) Elix \& Lumbsch - [PR, EN], on birch tree bark: 11.

Polycauliona candelaria (L.) Th. Fr. - on wood: 7.

P. polycarpa (Hoffm.) Th. Fr. ex Rieber - on birch tree bark: 3, 7.

Porpidia crustulata (Ach.) Hertel \& Knoph - on stones: 16, 25.

Protoparmeliopsis muralis (Schreb.) Choisy - on stones: 16, 20.

Pseudevernia furfuracea (L.) Zopf - on pine tree bark: 1, 11, 29.

Rhizocarpon geographicum (L.) DC. - on stone: 16.

!R. polycarpum (Hepp) Th. Fr. - on stone: 16.

!Rufoplaca arenaria (Pers.) Arup, Søchting \& Frödén - on soil: 24.

Rusavskia elegans (Link) Th. Fr. - on stones: 16, 20.

Scoliciosporum chlorococcum (Graeve ex Stenh.) Vězda - on pine, and birch tree bark: 1, 3, 53.

!Stereocaulon condensatum Hoffm. - [PR, VU], on soil: 6.

!S. incrustatum Flörke - [PR, EN], on soil: 6.

!Trapelia placodioides Coppins \& P. James - on stone: 16.

Trapeliopsis flexuosa (Fr.) Coppins \& P. James - on wood: 6, 10.

T. granulosa (Hoffm.) Lumbsch - on soil, and dead bark: 6, 7, 10, 39, 41, 46, 57.

Tuckermanopsis chlorophylla (Willd.) Hale - [PR, VU], on birch, and oak tree bark: 11, 48.

Usnea hirta (L.) Weber ex F.H. Wigg. - [PR, VU], on birch tree bark: 2.

!Verrucaria nigrescens Pers. - on stones, and on concrete posts: 16.

Vulpicida pinastri (Scop.) J. E. Mattson \& M. J. Lai - [PR, NT], on birch tree bark: 11.

Xanthoparmelia loxodes (Nyl.) O. Blanco \& al. - [PR], on stone: 40.

$X$. parietina (L.) Th. Fr. - on birch tree bark: 3, 7, 18, 20, 46, 47, 49. 


\section{References}

Aptroot, A., van Herk, C.M., Sparrius, L.B. (2011). Basisrapport voor de Rode Lijst Korstmossen. BLWG Rapport, 12, 1-108.

Ceynowa-Giełdon, M. (1993). Lichens of the genus Collema by the lower Vistula. Acta Mycologica, 1 (28), $53-59$

Ceynowa-Giełdon, M. (2001). Calciphilous terricolous lichens in Kujawy. Toruń: Wydawnictwo Uniwersytetu Mikołaja Kopernika w Toruniu.

Ceynowa-Giełdon, M., Glazik, N. (1994). Rzadkie porosty kserokontynentalne na obszarze Dolnej Wisły. Fragmenta Floristica et Geobotanica, Seria Polonica, 1, 41-47.

Ceynowa-Giełdon, M., Adamska, E., Kamiński, D. (2004). Porosty w dolinie dolnej Wisły i na obszarze przemysłowym Kujaw. In:. E. Karasińska-Korczyńska, M. Korczyński, (eds.), Wycieczki geobotaniczne. Region kujawsko-pomorski (pp. 13-22). Bydgoszcz-Toruń: Wydawnictwo Polskie Towarzystwo Botaniczne Oddział Toruński, Oddział Bydgoski.

Ciaciura, M., Lasowska, A., Bosiacka, B. (2008). Lichens of the "Karpaty Cedyńskie" area in the northwestern Poland. Badania Fizjograficzne nad Polska Zachodniq ser. B. Botanika, 57, 89-98.

Cieśliński, S., Czyżewska, K., Fabiszewski, J. (2006). Red List of extinct and threatened lichens in Poland. In: Z. Mirek, K. Zarzycki, W. Wojewoda, Z. Szeląg (eds.), List of plants and fungi in Poland (pp. 71-89). Kraków: W. Szafer Institute of Botany, Polish Academy of Sciences.

Czyżewska, K. (1986). Flora porostów naziemnych w Załęczańskim Parku Krajobrazowym (Wyżyna Wieluńska). Acta Universitatis Lodziensis, Folia Sozologica, 2, 315-341.

Ćwikliński, B. (1976). Rezerwat krajobrazowy „Wrzosy Cedyńskie”. Urząd Wojewódzki w Szczecinie, Wydział Ochrony Środowiska i Gospodarki Wodnej. Dokumentacja Przyrodnicza, 1-7.

Dolnik, C., Stolley, G., Zimmer, D. (2010). Die Flechten Schleswig-Holsteins Rote Liste, 3. Fassung. Flintbek: Landesamt für Landwirtschaft, Umwelt und ländliche Räume.

Fałtynowicz, W. (1992). The lichens of Western Pomerania (NW Poland): an ecogeographical study. Polish Bot. Stud., 4.

Fałtynowicz, W., Kossowska, M. (2016). The lichens of Poland. A fourth checklist. Acta Botanica Silesiaca Monographiae, 8, 3-122.

Glanc, K. (1964). Lecidea decipiens (Ehrh.) Ach. i inne interesujące gatunki porostów w murawach kserotermicznych północno-zachodniej Polski. Fragmenta Floristica et Geobotanica, 2 (10), 263-267.

Hauck, M., de Bruyn, U. (2010): Rote Liste und Gesamtartenliste der Flechten in Niedersachsen und Bremen. Informationsdienst Naturschutz Niedersachsen, 30, 1-84.

Litterski, B., Schiefelbein, U. (2007). Rote Liste der Flechten Mecklenburg-Vorpommerns. Ministerium für Landwirtschaft, Umwelt und Verbraucherschutz (ed.). Schwerin: Turo-Print.

Matuszkiewicz, W. (2001). Przewodnik do oznaczania zbiorowisk roślinnych Polski. Vademecum Geobotanicum 3. Warszawa: Państwowe Wydawnictwo Naukowe.

Otte, V., Rätzel, S. (2004). Kommentiertes Verzeichnis der Flechten und flechtenbewohnenden Pilze Brandenburgs, Deutschland. Feddes Repertorium, 1-2 (115), 134-154.

Søchting, U., Alstrup, V. (2008). Danish Lichen Checklist. Version 2. Faculty of Science, University of Copenhagen.

Tobolewski, Z. (1962). Materiały do flory porostów północno-zachodniej Polski. Fragmenta Floristica et Geobotanica, 1 (8), 67-80.

Wieczorek, A. Schiefelbein, U. (2013). Lichens of xerothermic grasslands in Western Pomerania (Poland). Plant Div. Evol., 3-4 (130), 295-302. 
Wójciak, H. (1987). Flora porostów wapiennych zboczy w Dobrem koło Kazimierza Dolnego nad Wisłą. Annales Universitatis Marie Curie-Sklodowska, Sectio C, 9 (42), 103-108.

Ziarnek, K., Waloch, P., Wieczorek, A., Michalska, M., Wolender, M., Zycha, A., Zyska, P., Zyska, W. (2006). Projekt planu ochrony rezerwatu przyrody ,,Wrzosowiska Cedyńskie”. Szczecin: Biuro Konserwacji Przyrody w Szczecinie (mscr.)

Cite as: Wieczorek, A., Łysko, A. (2017). Lichen biota of the "Wrzosowiska Cedyńskie im. inż. Wiesława Czyżewskiego" nature reserve in the Cedynia Landscape Park (NW Poland). Acta Biologica, 24, 159-169. DOI: 10.18276/ab.2017.24-14. 
